\title{
Biosensor for determination of glucose in real samples of beverages
}

\author{
Biossensor para determinação de glicose em amostras reais de bebidas
}

\author{
Flavio Marques LOPES ${ }^{1}$, Karla de Aleluia BATISTA ${ }^{1}$, Gustavo Luiz Aleluia BATISTA ${ }^{1}$ Kátia Flávia FERNANDES ${ }^{1 *}$
}

\begin{abstract}
A biosensor was developed for spectrophotometric determination of glucose concentrations in real samples of orange juice energetic drinks, and sport drinks. The biosensor consisted of glucose oxidase (GOD) and horseradish peroxidase (HRP) immobilized onto polyaniline activated with glutaraldehyde (PANIG). Immobilization parameters were optimized for GOD, and maximum immobilization yield was $16 \%$ when $5.0 \mathrm{mg}$ of PANIG and $8.9 \mathrm{U}$ prepared in $0.1 \mathrm{~mol} . \mathrm{L}^{-1}$ sodium phosphate buffer $(\mathrm{pH} 7.0)$ reacted for 60 minutes at $4{ }^{\circ} \mathrm{C}$ with gentle stirring. The linear operational range for glucose determination using optimized operational parameters was between 0.05 and $6.0 \mathrm{mg} . \mathrm{mL}^{-1}$ with a very good reproducibility of response. The results obtained in the biosensor were compared with those obtained using free enzymes (commercial kits) and then validated through statistical analysis using the Tukey test (95\% confidence interval).

Keywords: biosensor; glucose; glucose oxidase; immobilization; polyaniline.
\end{abstract}

\section{Resumo}

Foi desenvolvido um biossensor espectrofotométrico para a determinação da concentração de glicose em amostras reais de suco de laranja, energéticos e bebidas esportivas. O biossensor consistiu de glicose oxidase (GOX) e peroxidase (HRP) imobilizadas em polianilina ativada com glutaraldeído (PANIG). Os parâmetros de imobilização foram otimizados para a GOX e o rendimento máximo de imobilização obtido foi de $16 \%$ para $5 \mathrm{mg}$ de PANIG e 8,9 Unidades de Enzima (UE) preparadas em tampão fosfato 0,1 mol.L ${ }^{-1}$ (pH 7,0) com tempo de reação de 60 minutos a $4{ }^{\circ} \mathrm{C}$, com agitação leve. Utilizando os parâmetros otimizados, encontrou-se uma faixa linear para a determinação de glicose entre 0,05 e $6,0 \mathrm{mg} \cdot \mathrm{mL}^{-1}$, com boa reprodutibilidade de resposta. Os resultados obtidos foram comparados com resultados de enzimas livres (kits comerciais), sendo validados através de análise estatística pelo teste de Tukey ( $95 \%$ de significância).

Resumo: biossensor; glicose; glicose oxidase; imobilização; polianilina.

\section{Introduction}

Starch is one of the biomolecules that appears frequently in food composition due to its physical properties, and because it acts as a source of glucose and therefore of energy (DEMIATE; KONKEL; PEDROSO, 2001; WEBER; COLLARES-QUEIROZ; CHANG, 2009). The proliferation of microorganisms in foodstuffs is directly dependent on their ability to hydrolyze starch releasing glucose that will be the primary source of energy for growth. In this case, increase in glucose concentration may be an important and early indicator of contamination.

The determination of glucose concentration is also particularly important in some food products since glucose causes browning during dehydration and long-term storage, mainly due to the Maillard reaction. This is a major obstacle in the manufacture of dehydrated egg powder (D'SOUZA; GODBOLE, 1989), and it is also a serious problem in hydrolysis of high molecular weight dextrans to oligosaccharides, utilized in the production of pharmaceutical products. The resulting colored compounds are not compatible with pharmaceutical and food rules for formulation acceptability (MISLOVICOVÁ; MICHÁLKOVÁ; VIKARTOVSKÁ, 2007). Therefore, the quantitative determination of glucose constitutes an important measurement in food product quality control.
Numerous methods have been reported for glucose analysis in food. However, most of the current adopted methods are time consuming or costly (AQUINO et al., 2004; WU et al., 2004; DRUZIAN; DOKI; SCAMPARINI, 2005; YILDIZ et al., 2005). Currently, several devices are available for precise and prompt glucose measurements in the clinical area, but these devices are frequently designed to operate under blood serum conditions. Development of fast, cheap, practical, and selective methods for detecting glucose in food is still a research area that brings together efforts from chemistry to clinical analysis.

Enzymatic determinations of glucose involve glucose oxidase (E.C. 1.1.3.4.) (GOD) and horseradish peroxidase (E.C. 1.11.1.7) in a sequence of redox reactions. Glucose oxidase as a free enzyme has been used in the measurement of glucose in foods and beverages (ÇIL et al., 2007; WILSON; TURNER, 1992; SARTINI et al., 1998) even though it represents an important cost component of a product (WU et al., 2004). To overcome this inconvenience, GOD has been immobilized on various supports with the purpose of its economic reuse (MISLOVICOVÁ; MICHÁLKOVÁ; VIKARTOVSKÁ, 2007; ENDO et al., 2006; FERREIRA; FIORITO; OLIVEIRA JUNIOR, 2004; GÜRSEL et al., 2003). Examples of the use of immobilized

Received 22/3/2010

Accepted 15/11/2010 (004747)

1 Laboratório de Química de Proteínas, Departamento de Bioquímica e Biologia Molecular, Instituto de Ciências Biológicas, Universidade Federal de Goiás - UFG, CP 131, CEP 74001-970, Goiânia, GO, Brazil,e-mail: karla-batista@hotmail.com

${ }^{*}$ Corresponding author

DOI: http://dx.doi.org/10.1590/S0101-20612012005000003 
GOD in food production are the preparation of gluconic acid (RAMACHANDRAN et al., 2006; BAO et al., 2004; FIEDUREK, 2001), removal of oxygen from beer (HARTMEIER; WILLOX, 1981), and the removal of glucose from eggs (SISAK et al., 2006; SANKARAN; GODBOLE; D’SOUZA, 1989; D'SOUZA; GODBOLE, 1989). When immobilized in biosensors, GOD is also used for the removal of glucose from pentosan of wheat flour (HOUBEN; RUIJTER; BRUNT, 1997), and health control of farm fish (ENDO et al., 2006). In spite of its wide application, the most common and serious problem of GOD biosensors is their lack of stability because of the intrinsic nature of the enzyme (KANG et al., 2007)

In a previous study, we showed a spectrophotometric device for hydrogen peroxide measurement using horseradish peroxidase (HRP) immobilized on polyaniline (FERNANDES et al., 2005). This device was used to measure glucose in a combination with free GOD. In the present paper, the development of a cheap and stable biosensor containing HRP and immobilized GOD and its use for spectrophotometric determination of glucose in real samples of sport drinks, soft drinks, and orange juice, is described.

\section{Materials and methods}

\subsection{Reagents}

Horseradish peroxidase (HRP) type VI was purchased from Sigma Chemical Co. (St. Louis, MO, USA). Glucose oxidase

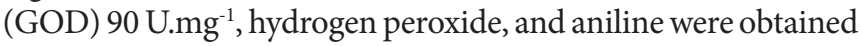
from E. Merck (Darmstadt, Germany). Aniline was distilled under vacuum obtaining a colorless liquid. Energil $\mathrm{C}$ and orange juice were produced by Tampico - Tampico Beverages Inc., Chicago - IL, EUA. On Line and Fly horse were produced by AmBev - GlobalBev, Marathon by Fratelli Vita - AmBev GlobalBev. Red bull and Gatorade were produced by Quaker Oats Company. All other reagents were analytical grade and were used without further purification. Solutions were prepared with deionized water.

\subsection{Polymer synthesis and activation}

Polyaniline (PANI) was chemically synthesized as described previously (FERNANDES et al., 2003) using ammonium persulphate as the oxidizing agent. The black/green powder obtained was activated with a $2.5 \%(\mathrm{v} / \mathrm{v})$ glutaraldehyde solution, under reflux, for 2 hours to obtain glutaraldehydemodified polyaniline (PANIG). After exhaustively washing with 0.1 mol. $\mathrm{L}^{-1}$ phosphate buffer, $\mathrm{pH}$ 6.0, the powder was dried under dynamic vacuum and stored at room temperature until its use for enzyme immobilization.

\subsection{Immobilization and assay}

The immobilization of HRP was carried out as described previously (FERNANDES et al., 2003) resulting in 8.2 U HRP.mg $^{-1}$ PANIG, which represents a $24.3 \%$ yield.

The optimum immobilization conditions of glucose oxidase (PANIG-GOD) were obtained varying the enzyme and polyaniline (PANIG) concentration, the $\mathrm{pH}$, and the time of the immobilization reaction. The reactions were performed at $4{ }^{\circ} \mathrm{C}$. After immobilization, PANIG-GOD was washed with 0.1 mol.L $\mathrm{L}^{-1}$ phosphate buffer $\mathrm{pH} 7.0$ to remove unbounded enzyme molecules.

Measurements of GOD immobilization were performed by adding $2.8 \mathrm{~mL}$ of freshly prepared substrate solution containing $41.05 \mathrm{mmol} . \mathrm{L}^{-1}$ phenol, $0.6 \mathrm{mmol} . \mathrm{L}^{-1} 4$-aminoantipyrine, both prepared in 0.1 mol. $\mathrm{L}^{-1}$ phosphate buffer, and $\mathrm{pH} 7.0$ to PANIG-GOD. The reaction was started by the addition of $20 \mu \mathrm{L}$ of glucose solution $\left(0.05\right.$ to $\left.6 \mathrm{mg} \cdot \mathrm{mL}^{-1}\right)$ which were left to occur for 10 minutes. The product formed was analyzed using a spectrophotometer at $510 \mathrm{~nm}$. All measurements were performed in triplicates, and the results were presented as mean and standard deviation.

\subsection{Reactor design}

The biosensor was constructed as an air-lift reactor consisting of $5.0 \mathrm{mg}$ of PANIG-HRP and $5.0 \mathrm{mg}$ of PANIG-GOD assembled into a polypropylene reaction camera connected to an air pump, an upper connection for substrate input and a lower valve for product exit. The products were pumped through a detection system consisting of a spectrophotometer connected to a recorder. Optical density was recorded every 5 seconds at $510 \mathrm{~nm}$ in a glass cell with $1.0 \mathrm{~mm}$ optical path length (Figure 1). The relationship between PANIG-HRP and PANIG-GOD amounts in the reaction camera were optimized to obtain the best performance of the system.

\subsection{Operational range for glucose determination and operational stability of the biosensor}

The system was operated at room temperature. The operations consisted of filling the reaction camera containing the immobilized enzymes with substrate solution (2.2). $20 \mu \mathrm{L}$ injections of increasing concentrations of glucose samples $(0.05$ a $\left.6.0 \mathrm{mg} . \mathrm{mL}^{-1}\right)$ started the reactions, which were left to proceed for 10 minutes. Next, the exit valve was opened, and the product formed was pumped to the detection system. The residence time was tested from 1 to 30 minutes. Only measurements higher

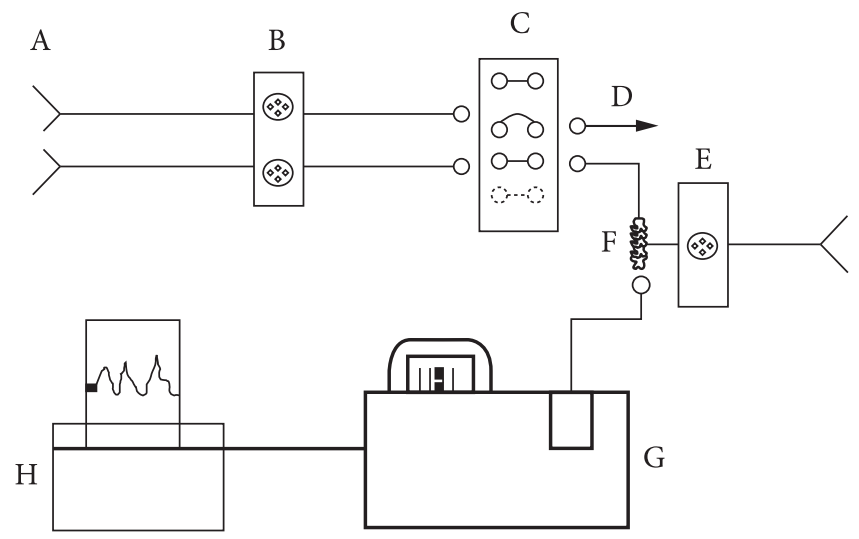

Figure 1. Biosensor for glucose determination. A: substrate or buffer input; B: pump ; C: commutation valve; D: substrate or buffer output; E: air pump; F: reaction camera; G: spectrophotometer; H: recorder. 
than 0.4 EU was considered to establish the inferior limit of detection. Readings below this value were considered as noise.

The operational stability of the biosensor was tested by sequential injections of glucose samples followed by washes with phosphate buffer.

\subsection{Determination of glucose in real samples}

The amount of glucose in real samples was determined using biosensor. The tests were performed in triplicates, and the results were presented as mean and standard deviation. The operations consisted of filling the reaction camera containing the immobilized enzymes with the substrate solution (2.2). Injections of $20 \mu \mathrm{L}$ of the beverages samples started the reactions which were left to proceed for 10 minutes. Next, the exit valve was opened, and the product formed was pumped to the detection system. The data obtained using the biosensor were compared with the glucose amounts determined via glucose oxidase method using free GOD and HRP (HENRY, 1996). Total sugar concentration was measured using the Dubois (phenol sulphuric) method (1956).

\subsection{Statistical analysis}

All experiments were performed at least three times in triplicate with three independent samples. The analysis of variance (ANOVA) and comparison between means values were applied to establish differences using the Tukey test (confidence interval 95\%). All analyses were carried out using the Statistica 6.0 software.

\section{Results and discussion}

\subsection{GOD immobilisation}

The immobilization parameters were optimized for GOD resulting in a maximum immobilization yield of $16 \%$ when $5.0 \mathrm{mg}$ of PANIG and 8.9 EU prepared in $0.1 \mathrm{~mol} . \mathrm{L}^{-1}$ phosphate buffer, $\mathrm{pH} 7.0$, were left to react for 60 minutes, at $4{ }^{\circ} \mathrm{C}$ under gently stirring. Figure 2 shows that $\mathrm{pH}$ seems to be an important immobilization factor because variations of one $\mathrm{pH}$ unit resulted in a significant increase in the immobilized enzyme content. This variation was probably caused by the state of ionization of the lateral chains of the lysine residues present on the exposed surface of GOD since these are the targets for reaction with the carbonyl groups of glutaraldehyde to form Schiff bases (ARTIGO LU). Furthermore, as can be seen in Figure 3, increases in enzyme concentration resulted in increases in the amount of immobilized enzyme. Efficiency of immobilization in the optimized conditions was higher than those found by Du et al. (2009), who reported a yield of 3.36\% when GOD was immobilized in Poly (St-GMA-NaSS) microspheres with and without BSA-spacer.

\subsection{Operational range for glucose determination}

Figure $4 \mathrm{a}, \mathrm{b}, \mathrm{c}$ shows the response obtained in the biosensor for three independent glucose injections. The operational range for glucose determination was stated from 0.05 to $6.0 \mathrm{mg} \cdot \mathrm{mL}^{-1}$.

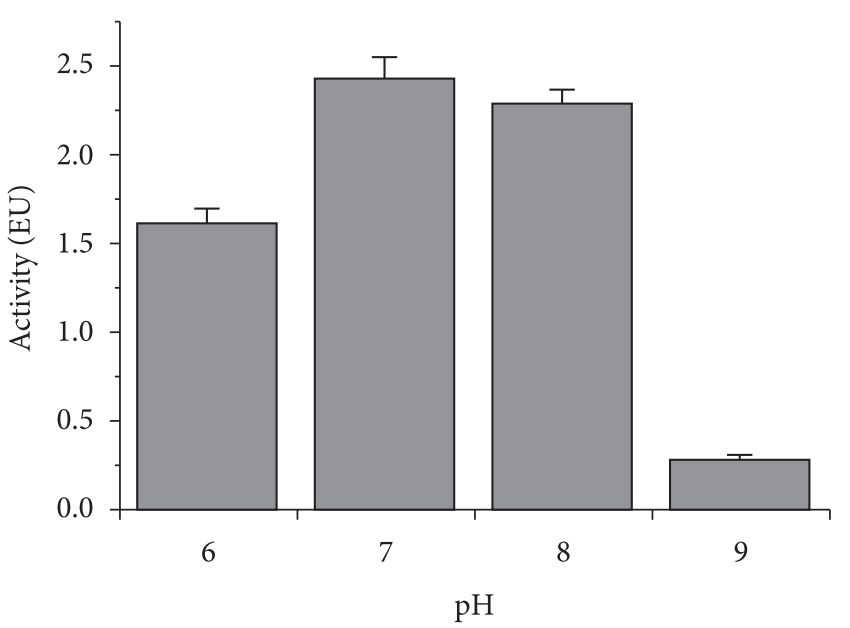

Figure 2. Activity of immobilized GOD versus the $\mathrm{pH}$ of immobilization.

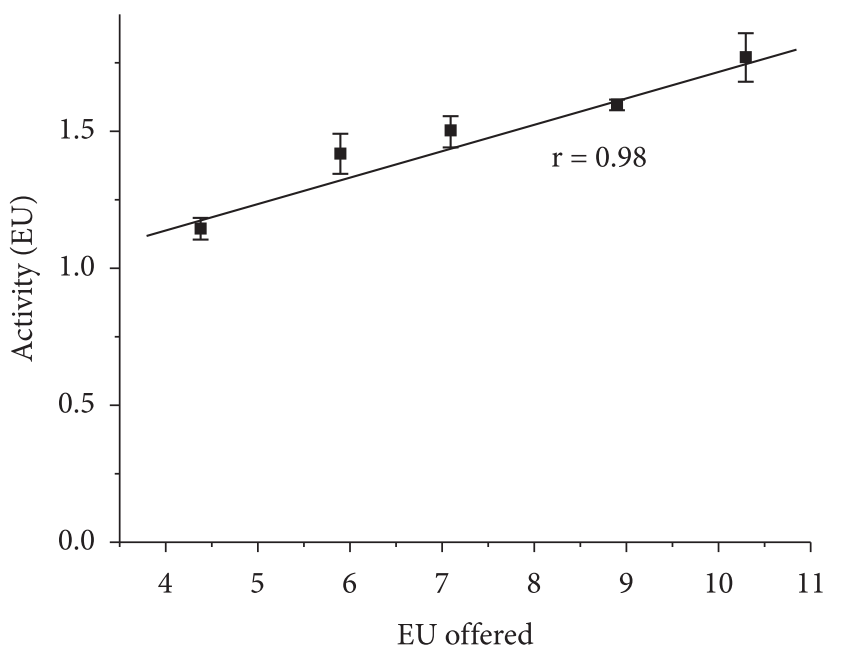

Figure 3. Activity of immobilized GOD versus the amount of enzyme added to PANIG.
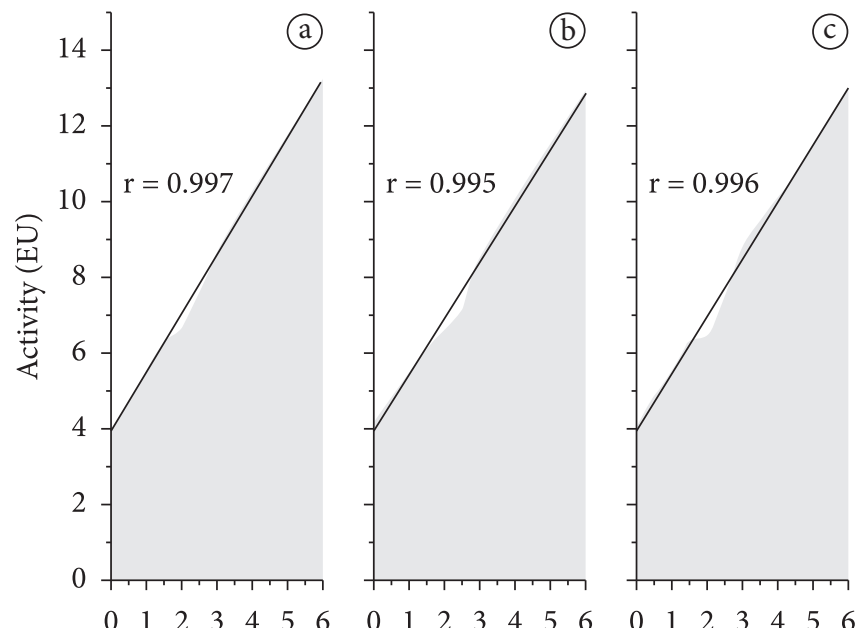

Glucose concentration mg. $\mathrm{mL}^{-1}$

Figure 4. Response linearity and reproducibility of biosensor. Each set of responses ( $\mathrm{a}, \mathrm{b}$, and c) corresponds to an independent biosensor and each point of response to a mean of at least three assays. 
Table 1. Amounts of carbohydrate and glucose in real samples.

\begin{tabular}{|c|c|c|c|c|c|}
\hline \multicolumn{2}{|c|}{ Beverage } & \multirow{2}{*}{$\begin{array}{c}\begin{array}{c}\text { Carbohydrates } \\
\left(\mathrm{mg} \cdot \mathrm{mL}^{-1}\right)^{*}\end{array} \\
60\end{array}$} & \multirow{2}{*}{ 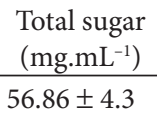 } & \multirow{2}{*}{$\begin{array}{c}{ }^{* *} \begin{array}{c}\text { Glucose }- \text { biosensor } \\
\left(\mathrm{mg} \cdot \mathrm{mL}^{-1}\right)\end{array} \\
53.7 \pm 3.6\end{array}$} & \multirow{2}{*}{$\begin{array}{c}{ }^{* *} \text { Glucose - with free enzymes } \\
\left(\mathrm{mg} \cdot \mathrm{mL}^{-1}\right)\end{array}$} \\
\hline Sport drinks & Gatorade & & & & \\
\hline & Marathon & 60 & $87.74 \pm 2.6$ & $48.5 \pm 3.2$ & $36.26 \pm 0,18$ \\
\hline & Energil C & 60 & $93.4 \pm 4.4$ & $50.4 \pm 2.8$ & $46.2 \pm 0.5$ \\
\hline \multirow[t]{3}{*}{ Energetic drinks } & On line & 116 & $119.9 \pm 4.6$ & $67.7 \pm 1.0$ & $61.8 \pm 1.3$ \\
\hline & Red Bull & 112 & $151.5 \pm 3.3$ & $64 \pm 3.4$ & $67.1 \pm 2.1$ \\
\hline & Flying Horse & 114 & $125.9 \pm 4.2$ & $47 \pm 3.7$ & $49 \pm 1.2$ \\
\hline Orange juice & Tampico & 120 & $108.7 \pm 5.0$ & $53.6 \pm 3.3$ & $48.9 \pm 0.8$ \\
\hline
\end{tabular}

${ }^{\star}$ Informed by the manufacturer. ${ }^{*}$ The results did not present meaningful statistical differences in the Tukey test.

As can be seen, the system is able to determine glucose with high reproducibility and linearity of response ( $a, r=0.997 ; b$, $\mathrm{r}=0.995$, and $\mathrm{c}, \mathrm{r}=0.996)$.

The results obtained showed that the operational range for glucose determination ( 0.05 to $6 \mathrm{mg} \cdot \mathrm{mL}^{-1}$ ) used in this study was larger than that reported by Duong and Rhee (2007), who obtained values of the detection limit between 0.10-0.52 mg.mL $\mathrm{mL}^{-1}$.

\subsection{Long-term stabilities of GOD/HRP biosensor}

To evaluate long-term stabilities of the biosensor, the responses were monitored during continuous use. As can be seen in Figure 5, the biosensor was used in 25 cycles for glucose determination without any loss in sensitivity. This finding is very important since it combines the stability of two immobilized enzymes: HRP and GOD. A preliminary study showed that HRP immobilized onto polyaniline was very stable for hydrogen peroxide determination (FERNANDES et al., 2005). Several authors reported stability of enzyme biosensors containing immobilized GOD (ÇIL et al., 2007; MISLOVICOVÁ; MICHÁLKOVÁ; VIKARTOVSKÁ, 2007; YILDIZ et al., 2005; FERREIRA; FIORITO; OLIVEIRA JUNIOR, 2004; GÜRSEL et al., 2003). The variation observed in this parameter is very high, and as such it is possible to find stabilities from $45 \%$ of initial activity after 5 days of use and storage to $90 \%$ of initial activity after 45 cycles of use. Based on these data, the biosensor described here presents good stability, especially considering the ease of the polymer synthesis, immobilization, and the operation of the device.

\subsection{Determination of glucose amount in real samples}

Several sport and energetic drinks as well as orange juice were analyzed for their glucose contents using a GOD/HRP biosensor and also by a free enzyme system. Table 1 shows the results of glucose determination in the biosensor and the use of the free enzymes.

As can be seen, there was a close relationship between the values found for the glucose measurements in the biosensor and those obtained with free enzymes. Slightly higher variations were observed among the total amounts of carbohydrates informed by the manufacturer and those obtained by the phenol-sulphuric method.

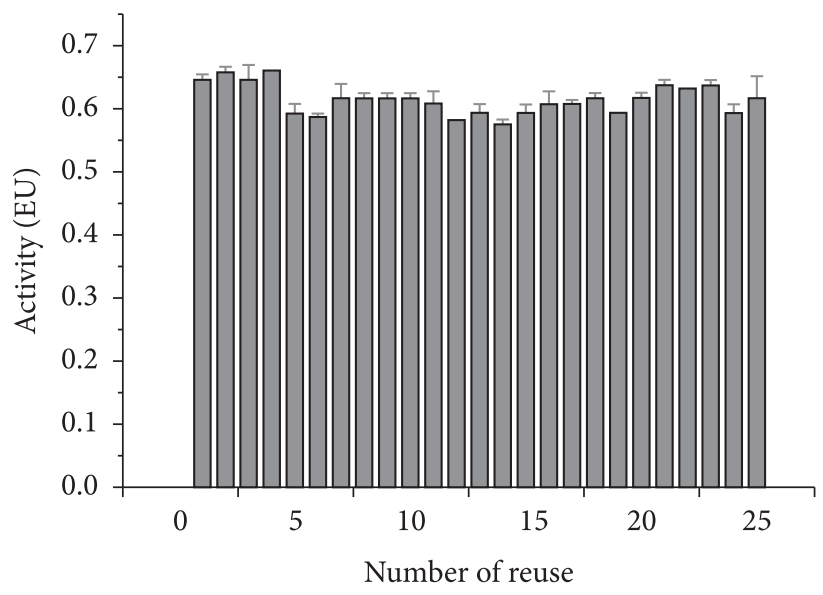

Figure 5. Repeated use of the mini-reactor. The results are presented as a percentage of the remaining activity versus assay number.

One interesting finding of this study was the absence of interference in the measurements. The composition of energetic beverages and soft drinks presents several compounds which can interfere in the performance of enzymes. Compounds such as citric acid, ascorbic acid, and several others may interfere in the reactions catalyzed by both GOD and HRP. Other components of these drinks may be oxidized by hydrogen peroxide produced in the HRP reaction hindering the GOD reaction. Particularly, biosensors can suffer from polymer interference if the support used for immobilization act as an adsorbing component. The absence of interference in the case of PANIG-GOD-HRP is a very interesting finding.

\section{Conclusion}

This study showed that GOD and HRP can be successfully immobilized in PANIG polymer, and that the biosensor resulting from this procedure represented a cheap, fast, and practical alternative to glucose determination in the samples tested. The biosensor showed high reproducibility of response and high stability during repeated use. Another important characteristic of this biosensor was the wide range of detection. The absence of interference of the components in the samples, especially ascorbic acid in the orange juice and citric acid in all the other beverages, was a very important finding of this research opening up the possibility of a wide range of application possibilities of this biosensor. 


\section{References}

AQUINO, F. W. B. et al. Determinação de aditivos, aldeídos furânicos, açúcares e cafeína em bebidas por cromatografis líquida de alta eficiência: validação e metologias. Ciência e Tecnologia de Alimentos, v. 24, n. 1, p. 32-38, 2004. http://dx.doi.org/10.1590/ S0101-20612004000100007

BAO, J. et al. Deactivation kinetics of immobilized glucose oxidase for production of calcium gluconate in an external loop airlift bioreactor. Biochemical Engineering Journal, v. 22, n. 1, p. 33-41, 2004. http://dx.doi.org/10.1016/j.bej.2004.08.001

ÇIL, M. et al. Various applications of immobilized glucose oxidase and polyphenol oxidase in a conducting polymer matrix. International Journal of Biological Macromolecules, v. 41, n. 1, p. 49-55, 2007. http://dx.doi.org/10.1016/j.ijbiomac.2006.12.005PMid:17291580

D'SOUZA, S. F.; GODBOLE, S. S. Removal of glucose from egg prior to spray drying by fermentation with immobilized yeast cells. Biotechnology Letters, v. 11, n. 3, p. 211-222, 1989. http://dx.doi. org/10.1007/BF01026061

DEMIATE, I. M.; KONKEL, F. E.; PEDROSO, R. A. Enzymatic determination of starch in doce de leite using dialysis. Ciência e Tecnologia de Alimentos, v. 21, n. 3, p. 339-342, 2001. http://dx.doi. org/10.1590/S0101-20612001000300016

DRUZIAN, J. I.; DOKI, C.; SCAMPARINI, A. R. P. Determinação simultânea de açúcares e polóis por cromatografia líquida de alta eficiência (CLAE-IR) em sorvetes de baixas calorias ("diet"/"light"). Ciência e Tecnologia de Alimentos, v. 25, n. 2, p. 279-284, 2005. http://dx.doi.org/10.1590/S0101-20612005000200017

DU, T. et al. Covalent immobilization of glucose oxidase onto Poly(StGMA-NaSS) monodisperse microspheres via BSA as spacer arm. Applies Surface Science, v. 255, p. 7937-7941, 2009. http://dx.doi. org/10.1016/j.apsusc.2009.04.172

DUBOIS, M. et al. Colorimetric method for determination of sugars and related substances. Analytical Chemistry, Washington, v. 28, n. 3, p. 350-356, 1956.

DUONG, H. D.; RHEE, J. I. Preparation and characterization of sensing membranes for the detection of glucose, lactate and tyramine in microtiter plates. Talanta, v. 72, p. 1275-1282, 2007. PMid:19071756. http://dx.doi.org/10.1016/j.talanta.2007.01.028

ENDO, H. et al. A needle-type optical enzyme sensor system for determining glucose levels in fish Blood. Analytica Chimica Acta, v. 573-574, n. 28, p. 117-124, 2006. PMid:17723514. http://dx.doi. org/10.1016/j.aca.2006.04.068

FERNANDES, K. F. et al. Immobilization of Horseradish Peroxidase onto Polyaniline Polymers. Process Biochemistry, v. 38, n. 9, p. 1379-1384, 2003. http://dx.doi.org/10.1016/S00329592(03)00021-9

FERNANDES, K. F. et al. Hydrogen peroxide detection system consisting of chemically immobilised peroxide and spectrometer. Process Biochemistry, v. 40, p. 3441-3445, 2005. http://dx.doi. org/10.1016/j.procbio.2005.04.003

FERREIRA, M.; FIORITO, P. A.; OLIVEIRA JUNIOR, N. O. Enzymemediated amperometric biosensors prepared with the Layer-byLayer (LbL) adsorption technique. Biosensors and Bioelectronics, v. 19, n. 12, p. 1611-1615, 2004. PMid:15142594. http://dx.doi. org/10.1016/j.bios.2003.12.025
FIEDUREK, J. Production of gluconic acid by immobilized in pumice stones mycelium of Aspergillus niger using unconventional oxygenation of culture. Biotechnology Letters, v. 23, n. 21, p. 1789-1792, 2001. http://dx.doi.org/10.1023/A:1012461200152

GÜRSEL, A. et al. Immobilization of invertase and glucose oxidase in conducting H-type polysiloxane/polypyrrole block copolymers. Reactive and Functional Polymers, v. 57, n. 1, p. 57-65, 2003. http:// dx.doi.org/10.1016/j.reactfunctpolym.2003.07.004

HARTMEIER, W.; WILLOX, I. C. Immobilized glucose oxidase and its use for oxygen removal from beer. MSAA Technical Quarterly, v. 18, p.145-149, 1981.

HENRY, J. B. Clinical diagnosis and management by laboratory methods. 19. ed. Philadelphia: W.B. Saunders, 1996. p. 194-207, 423-426.

HOUBEN R.; RUIJTER, C. F.; BRUNT, K. Determination of pentosan content of wheat products by hydrolysis, glucose oxidase treatment and analysis by HPAEC/PAD. Journal of Cereal Science, v. 26, n. 1, p. 37-46, 1997. http://dx.doi.org/10.1006/jcrs.1996.0110

KANG, X. H. et al. A novel sensitive non-enzymatic glucose sensor. Chinese Chemical Letters, v. 18, n. 2, p. 189-191, 2007. http:// dx.doi.org/10.1016/j.cclet.2006.12.034

MISLOVICOVÁ, D.; MICHÁLKOVÁ, E; VIKARTOVSKÁ, A. Immobilized glucose oxidase on different supports for biotransformation removal of glucose from oligosaccharide mixtures. Process Biochemistry, v. 42, n. 4, p. 704-709, 2007. http:// dx.doi.org/10.1016/j.procbio.2006.11.001

RAMACHANDRAN, S. et al. Gluconic acid: properties, applications and microbial production. Food Technology and Biotechnology, v. 44, n. 2, p. 185-95, 2006.

SANKARAN, K.; GODBOLE, S. S.; D'SOUZA, S. F. Preparation of spray-dried, sugar free egg powder using glucose oxidase and catalase coimmobilized on cotton cloth. Enzyme and Microbial Technology, v. 11, n. 9, p. 617-619, 1989. http://dx.doi. org/10.1016/0141-0229(89)90091-4

SARTINI, R. P. et al. Determination of reducing sugars by flow injection gravimetry. Analytica Chimica Acta, v. 366, n. 1-3, p. 119-125, 1998. http://dx.doi.org/10.1016/S0003-2670(97)00725-3

SISAK, C. et al. Elimination of glucose in egg white immobilized glucose oxidase. Enzyme and Microbial Technology, v. 39, n. 5, p. 1002-1007, 2006. http://dx.doi.org/10.1016/j.enzmictec.2006.02.010

WEBER, F. H.; COLLARES-QUEIROZ, F. P.; CHANG, Y. K. Caracterização físico-química, reológica, morfológica e térmica dos amidos de milho normal, ceroso e com alto teor de amilose. Ciência e Tecnologia de Alimentos, v. 29, n. 4, p. 748-753, 2009. http://dx.doi.org/10.1590/S0101-20612009000400008

WILSON, R.; TURNER, A. P. F. Glucose oxidase: an ideal enzyme. Biosensors and Bioelectronics, v. 7, n. 3, p. 165-185, 1992. http:// dx.doi.org/10.1016/0956-5663(92)87013-F

WU, B. et al. Biosensors for determination of glucose with glucose oxidase immobilized on an eggshell membrane. Talanta, v. 64, n. 2, p. 546-553, 2004. PMid:18969638. http://dx.doi.org/10.1016/j. talanta.2004.03.050

YILDIZ, H. B. et al. Immobilization of glucose oxidase in conducting graft copolymers and determination of glucose amount in orange juices with enzyme electrodes. International Journal of Biological Macromolecules, v. 37, n. 4, p. 174-178, 2005. PMid:16321435. http://dx.doi.org/10.1016/j.ijbiomac.2005.10.004 